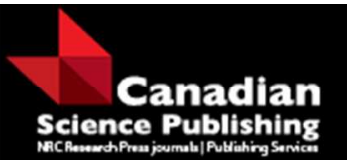

Canadian Journal of Forest Research Revue canadienne de recherche forestière

\title{
Cold hardiness of white spruce, black spruce, jack pine, and lodgepole pine needles during dehardening
}

\begin{tabular}{|r|l|}
\hline Journal: & Canadian Journal of Forest Research \\
\hline Manuscript ID & cjfr-2017-0119.R1 \\
\hline Date Submitted by the Author: & 08-May-2017 \\
\hline Complete List of Authors: & $\begin{array}{l}\text { Man, Rongzhou; Ontario Ministry of Natural Resources } \\
\text { Lu, Pengxin; Ontario Forest Research Institute } \\
\text { Dang, Qing-Lai; Lakehead University }\end{array}$ \\
\hline $\begin{array}{r}\text { Keyword: } \\
\text { Is the invited manuscript for } \\
\text { consideration in a Special } \\
\text { Issue? : }\end{array}$ & $\begin{array}{l}\text { conifer winter injury, dehardening curves, budbreak, relative electrolyte } \\
\text { leakage, visual assessment }\end{array}$ \\
\hline & \\
\hline
\end{tabular}

SCHOLARONE ${ }^{\text {m }}$

Manuscripts 
3 Cold hardiness of white spruce, black spruce, jack pine, and lodgepole pine needles during dehardening

5

6

$11{ }^{1}$ Ontario Ministry of Natural Resources and Forestry, Ontario Forest Research Institute, 1235

12 Queen Street East, Sault Ste. Marie, ON, P6A 2E5 Canada rongzhou.man@ontario.ca;

13 pengxin.lu@ontario.ca

14

$15 \quad{ }^{2}$ Faculty of Natural Resources Management, Lakehead University, Thunder Bay, ON P7B 5E1

16 qdang@lakeheadu.ca

17 
18 Abstract Conifer winter damage results primarily from loss of cold hardiness during

19 unseasonably warm days in late winter and early spring and such damage may increase in

20 frequency and severity under a warming climate. In this study, the dehardening dynamics of

21 lodgepole pine (Pinus contorta Dougl. ex. Loud), jack pine (Pinus banksiana Lamb.), white

22 spruce (Picea glauca (Moench) Voss), and black spruce (Picea mariana (Mill.) B.S.P.) were

23 examined in relation to thermal accumulation during artificial dehardening in winter (December)

24 and spring (March) using relative electrolyte leakage and visual assessment of pine needles and

25 spruce shoots. Results indicated that all 4 species dehardened at a similar rate and to a similar

26 extent, despite considerably different thermal accumulation requirements. Spring dehardening

27 was comparatively faster, with black spruce slightly hardier than the other conifers at the late

28 stage of spring dehardening. The difference, however, was relatively small and did not afford

29 black spruce significant protection during seedling freezing tests prior to budbreak in late March

30 and early May. The dehardening curves and models developed in this study may serve as a tool

31 to predict cold hardiness by temperature and to understand the potential risks of conifer cold

32 injury during warming/freezing events prior to budbreak.

33 Keywords: conifer winter injury, dehardening curves, budbreak, relative electrolyte leakage,

34 visual assessment 


\section{Introduction}

36 The ability of boreal conifers to survive winter cold depends not only on the level of cold

37 hardiness they can potentially achieve, but also on their responses to temperature fluctuations,

38 i.e., the ability to remain cold hardy during periods of warm days in late winter. In general,

39 changes in cold hardiness follow seasonal changes in photoperiod and temperature, increasing

40 with shorter photoperiod and lower temperatures in fall, reaching a maximum in mid-winter, and

41 decreasing with higher temperatures and longer photoperiod in spring (Bigras et al. 2001;

42 Pletsers et al. 2015). The level of maximum cold hardiness is generally well below minimum

43 temperatures that occur within a species' natural distribution range (Halfpenny and Ozannne

44 1989; Bannister and Neuner 2001; Strimbeck et al. 2015); therefore, well-hardened boreal

45 conifers are unlikely to suffer freezing injury from cold temperatures (Bannister and Neuner

46 2001). However, cold hardiness can be rapidly lost during natural dehardening (Bigras et al.

47 2001; Man et al. 2016), which typically occurs late winter to early spring (Sakai and Larcher

48 1987; Jönsson et al. 2004; Kalberer et al. 2006). During this period, episodes of unseasonably

49 warm days can be followed by seasonally cold days, resulting in winter freezing; such damage

50 has occurred on mature trees of a single species, such as lodgepole pine (Pinus contorta Dougl.

51 ex. Loud.; Henson 1952; Halfpenny and Ozannne 1989) and red spruce (Picea rubens Sarg.;

52 Strimbeck et al. 1995; Lund and Livingston 1999), and on saplings and mature trees of multiple

53 species over extensive areas (Cayford et al. 1959; Man et al. 2009, 2013).

Relative to level of maximum cold hardiness, the dehardening process is less well

55 documented, especially in relation to temperature changes, the primary factor influencing spring

56 dehardening (Bigras et al. 2001). Observations about the annual cold hardiness of several boreal

57 conifers indicate that spring dehardening occurs more rapidly than fall hardening and differs not 
58 only among species groups (e.g., between pine and spruce) (Glerum 1973; Repo 1992; Silim and

59 Lavender 1994), but also within species (Nilsson 2001; Ögren 2001) due to variations in chilling

60 and thermal accumulations for dormancy release and budbreak (Howe et al. 2003). Although

61 seasonal changes in cold hardiness are generally known (Bannister and Neuner 2001; Bigras et

62 al. 2001), quantitative links between these changes and cumulative spring temperature changes

63 are rarely established and, therefore, results are difficult to apply in modelling cold hardiness or

64 understanding the risks of conifer winter injury. As shown by Repo and Pelkonen (1986) and

65 Man et al. $(2014,2016)$, the rate of dehardening also varies with season in relation to progress

66 towards fulfilling chilling requirements and dormancy release.

67 The objectives of this study were to determine the change of cold hardiness during

68 dehardening in winter months in 4 Canadian conifer species: lodgepole pine, jack pine (Pinus

69 banksiana Lamb.), white spruce (Picea glauca) (Moench) Voss), and black spruce (Picea

70 mariana (Mill.) B.S.P.), and to examine variation among species in dehardening dynamics

71 before and after chilling requirements for dormancy release are met. Our hypothesis was that

72 since black and white spruce flush bud later than lodgepole pine and jack pine (Man et al. 2016)

73 they would be slower to lose cold hardiness during spring dehardening, which is when winter

74 freezing damage generally occurs (Cayford et al. 1959; Man et al. 2009, 2013).

75

76 Methods

77 Seedling materials

78 Lodgepole pine seedlings were initially grown in containers in a greenhouse at Tree Time

79 Services Inc./Coast to Coast Reforestation in Smoky Lake, Alberta, Canada, using seeds of open-

80 pollinated wild trees from southwest of Whitecourt, Alberta $\left(54^{\circ} 04^{\prime} \mathrm{N}, 116^{\circ} 41^{\prime} \mathrm{W}\right)$. Black 
81 spruce, white spruce and jack pine seedlings were initially grown in containers at the Millson

82 Forestry Service Inc. in Timmins, Ontario, using seeds from orchard trees established for the nearby Martel Forest area $\left(47^{\circ} 50^{\prime}-48^{\circ} 28^{\prime} \mathrm{N}, 82^{\circ} 15^{\prime}-83^{\circ} 25^{\prime} \mathrm{W}\right)$. After cold storage in early June 2013, 1-year-old container seedlings were shipped to Sault Ste. Marie, Ontario, for use in this study. Upon arrival, seedlings were transplanted into 4" square $(10 \mathrm{~cm}$ side x $15 \mathrm{~cm}$ deep) pots filled with 2:1 peat moss/vermiculite $(v / v)$ mixture and grown in the greenhouse at the Ontario Forest Research Institute. The seedlings received natural photoperiods with temperatures 2 to 5

${ }^{\circ} \mathrm{C}$ above ambient were watered as required using an automated spray walker, supplemented with hand watering, and fertilized weekly with 20-8-20 (N-P-K) (Plant Products Co Ltd, Brampton, $\mathrm{ON}$ ) at $100 \mathrm{ppm} \mathrm{N}$ for a month before being moved outdoors in early July. They were kept outdoors for three summers with weekly watering and biweekly fertilization following standard nursery practices (20-8-20 at 100 ppm $\mathrm{N}$ before mid-August and 20-20-20 at $50 \mathrm{ppm} \mathrm{N}$ from late August to mid-October), and received winter snow cover from late December to late March and natural hardening and dehardening under ambient photoperiod and temperatures (Fig. 1). Average height and basal diameter of the seedlings before the dehardening processes were studied were $61.5 \mathrm{~cm}$ and $9.5 \mathrm{~mm}$ for white spruce, $76.4 \mathrm{~cm}$ and $9.9 \mathrm{~mm}$ for black spruce, 75.3 $\mathrm{cm}$ and $11.5 \mathrm{~mm}$ for jack pine, and $66.2 \mathrm{~cm}$ and $11.1 \mathrm{~mm}$ for lodgepole pine, respectively.

\section{Dehardening conditions}

Artificial dehardening was applied to 8 seedlings of each species within each of the 3 replications (different growth chambers). Growth chambers were set at $15^{\circ} \mathrm{C} / 5^{\circ} \mathrm{C}$ (day/night) and $12 \mathrm{~h}$ photoperiod to represent average conditions from early April to early May in the study area, which is when spring dehardening generally occurs (Fig. 1). The dehardening experiment was 
104

105

106

107

108

109

110

111

112

113

114

115

116

117

118

119

120

121

122

123

124

125

126

carried out at two stages of winter development, one in early December when chilling requirement was about $90 \%$ complete on spruce and $50 \%$ on pine, and the other in early March when chilling requirement was about $100 \%$ complete on spruce and $90 \%$ on pine (Man, R., Lu, P., and Dang, Q.L., unpublished data). Seedlings were moved directly from the outdoor holding area into growth chambers in early December when ambient temperatures were generally above $0{ }^{\circ} \mathrm{C}$. In March dehardening, however, seedlings were conditioned at $-2{ }^{\circ} \mathrm{C}$ for a week, followed by a week of slow thawing at $2{ }^{\circ} \mathrm{C}$ to minimize temperature shock due to below freezing night temperatures (Fig. 1).

\section{Cold hardiness and budbreak assessments}

During the artificial dehardening period, seedling cold hardiness was determined by a series of freezing tests using tissue samples collected from seedlings from each of the experimental replications. Relative electrolyte leakage (REL) (Burr et al. 2001) was measured and needle discoloration was assessed visually. Intervals between freezing tests were 2 days at the early stage of dehardening and 4 or more days when changes in cold hardiness became more gradual. For each freezing test, current pine needle fascicles and spruce shoots (buds removed) were collected from top laterals of 6 seedlings within each replication. Samples were placed into 7 test tubes, with each test tube containing 6 pine needle fascicles or 61 -cm spruce shoot segments from 6 different seedlings. Three freezing test programs were used with testing temperatures of (1) $+4,-10,-20,-30,-40,-50$, and $-196{ }^{\circ} \mathrm{C}$ when complete needle death occurred below $-40{ }^{\circ} \mathrm{C}$; (2) $+4,-5,-10,-15,-20,-30$, and $-50{ }^{\circ} \mathrm{C}$ when complete needle death occurred between $-20{ }^{\circ} \mathrm{C}$ and $-40{ }^{\circ} \mathrm{C}$; and $(3)+4,-3,-6,-9,-12,-15$, and $-20{ }^{\circ} \mathrm{C}$ when complete needle death occurred between $-10{ }^{\circ} \mathrm{C}$ and $-20^{\circ} \mathrm{C}$. The freezing test programs were adjusted based on results of 
127 previous cold hardiness assessments to ensure that rapid changes in REL prior to needle death 128 were captured. After being rinsed with deionized water, the control (non-freezing) samples were 129 placed in a refrigerator at $+4{ }^{\circ} \mathrm{C}$ during freezing tests, with remaining samples subjected to the 130 testing temperatures described above in a programmable freezer (Thermotron ${ }^{\circledR}$ SM-32-C, 131 Holland, MI). Temperature inside the freezer was lowered at a rate of $5^{\circ} \mathrm{C} \mathrm{h}^{-1}$ for freezing test 132 programs (1) and (2) and $3{ }^{\circ} \mathrm{C} \mathrm{h}^{-1}$ for program (3) for better differentiation of cold hardiness 133 changes at the late stage of spring dehardening. Once a target temperature was reached, it was 134 held constant for 30 minutes. For samples targeted for $-196^{\circ} \mathrm{C}$, the temperature in the freezer 135 was lowered to $-68{ }^{\circ} \mathrm{C}$ at $5^{\circ} \mathrm{C} \mathrm{h}^{-1}$ before samples were immersed in $30 \mathrm{ml}$ liquid nitrogen. To 136 reduce post-freezing temperature change, frozen samples were stored at $-2{ }^{\circ} \mathrm{C}$ for 2 hours when 137 the testing temperatures were $\geq-10{ }^{\circ} \mathrm{C}$ or at $-10{ }^{\circ} \mathrm{C}$ for $1 \mathrm{~h}$ followed by at $-2{ }^{\circ} \mathrm{C}$ for $1 \mathrm{~h}$ when 138 testing temperatures were $<-10{ }^{\circ} \mathrm{C}$, before thawing in a refrigerator at $+4{ }^{\circ} \mathrm{C}$ overnight.

After thawing, $30 \mathrm{ml}$ of deionized water was added to each test tube, which was sufficient to submerge needles or shoot segments. Tubes were then covered with plastic caps and 141 incubated at room temperature $\left(20^{\circ} \mathrm{C}\right)$ for 4 days to enhance the release of diffusible electrolytes 142 from damaged tissues (Deans et al. 1995) and promote the development of observable damage 143 (Burr et al. 2001; Man et al. 2016). Initial post-freezing conductivity of the solution was 144 measured at $20^{\circ} \mathrm{C}$ with a Cole-Parmer Traceable Portable Conductivity Meter (Cole-Parmer 145 Instrument Company). The solutions and samples were then placed in a hot water bath at $90{ }^{\circ} \mathrm{C}$ 146 for 2 hours, cooled to room temperature, and measured for final post-killing conductivity after 24 147 hours. The REL was expressed as the ratio of initial to final conductivity. The level of tissue damage caused by freezing temperatures was assessed at the time of 149 initial post-freezing conductivity measurements. The three damage classes were: undamaged for 
150 healthy green needles and clear solution, damaged for partially discoloured (yellowish green for

151 pine and grey green for spruce) needles and somewhat cloudy solution, and dead for completely

152 discoloured (completely yellow for pine and totally pale for spruce) needles and cloudy solution.

153 Assessment consistency was validated by comparing needle and solution colour among freezing 154 temperatures and replications.

155 Seedlings subjected to dehardening conditions were monitored daily for terminal 156 budbreak and shoot elongation after first notice of bud swelling for each species. Buds were 157 considered flushed when bud scales were open (new needles clearly visible on spruce and shoot 158 elongation started on pine). Thermal accumulation was calculated as cumulative growing degree 159 hours (CGDH) above the threshold of $0{ }^{\circ} \mathrm{C}$ from start of dehardening conditions (Snyder et al. 160 1999; Man and Lu 2010). Cold hardiness assessments ended when buds were completely open 161 and black spruce shoots were elongating as it was the last of the 4 species to break bud.

163 Seedling freezing tests

164 Whole seedling freezing tests were conducted with outdoor-grown seedlings during natural 165 spring dehardening to confirm the results of cold hardiness assessments of needles and shoot 166 samples during artificial dehardening. The first freezing test was carried out March 19 to 21, 1672016 , at an early stage of spring dehardening when thermal accumulation $\left(\mathrm{CGDH}>0{ }^{\circ} \mathrm{C}\right.$ since 168 January 1) was about 1500 and there was no sign of budbreak in the 4 species. The second 169 freezing test was conducted May 2 to 4, 2016 at a late stage of spring dehardening when thermal 170 accumulation was about 5800 and jack pine and lodgepole pine had flushed and white spruce 171 buds had started to swell. 
At the time of the first seedling freezing test, outdoor night temperatures were about -5

$173{ }^{\circ} \mathrm{C}$. Seedlings were bagged and conditioned at $0{ }^{\circ} \mathrm{C}$ overnight before they were exposed to test 174 temperatures of $-15^{\circ} \mathrm{C},-25^{\circ} \mathrm{C}$, and $-35^{\circ} \mathrm{C}$ in a programmable freezer (Thermotron ${ }^{\circledR} \mathrm{SM}-32-\mathrm{C}$, 175 Holland, MI). At the time of the second freezing test, outdoor night temperatures were close to 0 $176{ }^{\circ} \mathrm{C}$ and seedlings were directly exposed to testing temperatures of $-5^{\circ} \mathrm{C},-10{ }^{\circ} \mathrm{C}$, and $-15^{\circ} \mathrm{C}$. The 177 freezer temperature was reduced at $5^{\circ} \mathrm{C} \mathrm{h}^{-1}$ for the first seedling freezing test and $3{ }^{\circ} \mathrm{C} \mathrm{h}^{-1}$ for the 178 second test; the later allowed for better differentiation of cold hardiness change at the late stage 179 of spring dehardening. After 30 minutes at the target temperature, seedlings were conditioned for 1802 hours at $-10{ }^{\circ} \mathrm{C}$ or $0{ }^{\circ} \mathrm{C}$ overnight before being returned outdoors. Each freezing treatment was 181 replicated 3 times (days), with 4 seedlings from each of the 4 species per replication. For both 182 freezing tests, unfrozen outdoor stored seedlings were used as controls. Percentage needle death was visually assessed 1 month after the first seedling freezing 184 tests and about 8 days after the second, which was when needle browning and mortality were 185 clearly visible.

187 Data analysis

188 Cold hardiness assessed using REL method was determined at LT50 (50\% tissue mortality) 189 through nonlinear regression of REL versus temperature for each replication and the formula by 190 Anderson et al. (1988):

$$
Y_{T}=Y_{\min }+\frac{Y_{\max }-Y_{\min }}{1+e^{k\left(T_{m}-T\right)}}
$$

192 where $Y_{\mathrm{T}}$ is the REL at temperature $T, Y_{\min }$ is the minimum value of the response variable for 193 non-stressed sample, $Y_{\max }$ is the maximum value of freeze-stressed samples, $k$ represents the 194 steepness of the response curve, and $T_{\mathrm{m}}$ is the midpoint of the symmetrical curve (an estimate of 
195 LT50). In black spruce and white spruce, the short exposure to liquid nitrogen did not kill all the 196 needles at the beginning of the dehardening process; as a result, the mean maximum values in 197 subsequent cold hardiness assessments of the same replications when needles were completely 198 dead were used.

The cold hardiness determined by visual assessment was the lowest damaged temperature 200 prior to complete needle death or midpoints between the lowest undamaged temperature and the 201 highest death temperature when damaged temperature was not captured. REL values were 202 interpolated to assist cold hardiness determination when lowest 'damaged' temperature was 203 between $-60{ }^{\circ} \mathrm{C}$ and $-196{ }^{\circ} \mathrm{C}$. Cold hardiness was compared among the conifer species tested using a randomized 205 complete block design with 4 treatments (species) and 3 replications (growth chambers). For 206 each cold hardiness assessment, multiple contrasts were conducted to examine differences in 207 cold hardiness among species when the species effect was significant $(P<0.05)$. The 208 randomized complete block design with 16 treatments (4 species and 4 freezing temperatures) 209 and 3 replications was also applied to each of the two whole seedling freezing tests (March and 210 May) to compare needle damage among species. Analyses were conducted using the statistical 211 software SAS (SAS 9.4, SAS Institute Inc. 2012).

\section{Results}

\section{Needle cold hardiness during dehardening}

215 Dehardening trends in needles were similar among the 4 species tested, with generally 216 faster and more advanced dehardening in March than December, although seedlings were more 217 cold hardy in March prior to artificial dehardening (Table 1; Figs. 2 and 3). Maximum cold 
218 hardiness prior to the March dehardening was below $-60{ }^{\circ} \mathrm{C}$, while the minimum cold hardiness 219 at the end of artificial dehardening was $-7^{\circ} \mathrm{C}$ to $-10^{\circ} \mathrm{C}$. Differences in cold hardiness among the 2204 species were significant at the early stage of December dehardening (CGDH $<4000)$, with 221 black spruce and white spruce $10{ }^{\circ} \mathrm{C}$ hardier than jack pine and $20{ }^{\circ} \mathrm{C}$ hardier than lodgepole 222 pine. At the late stage of March dehardening $(\mathrm{CGDH}>4000)$, black spruce was 2 to $3{ }^{\circ} \mathrm{C}$ hardier 223 than the other conifers (mostly lodgepole pine and occasionally white spruce). Jack pine showed 224 a greater gain in cold hardiness than other conifers in the December dehardening when the 225 seedlings were stored for 10 days at $0{ }^{\circ} \mathrm{C}$, covered in large plastic bags, between freezing tests. Fitting an exponential growth curve model $\left(a+b^{*}\left(1-\exp \left(-c^{*} x\right)\right)\right.$ to the mean cold 227 hardiness of March dehardening data indicated a dehardening rate (c) of 0.0006, 0.0007, 0.0007, 228 and 0.0006 , and minimum cold hardiness $(\mathrm{a}+\mathrm{b})$ of $-7.1,-8.2,-8.0$, and -10.4 for lodgepole pine, 229 jack pine, white spruce, and black spruce, respectively $\left(\mathrm{R}^{2}>0.95\right.$ for all). Corresponding values 230 for (a) were -69.6, 80.0, -85.2, and -69.9, and (b) were 62. 6, 71.7, 77.2, and 59.5. Fitting of the 231 December dehardening data produced an average dehardening rate (c) generally less than 0.0001 232 and $\mathrm{R}^{2}<0.83$.

233 Cold hardiness determined using REL and visual assessments was generally consistent, 234 with differences within 1 to $2^{\circ} \mathrm{C}$ for the species tested, except for the beginning of March 235 dehardening when cold hardiness was below $-60^{\circ} \mathrm{C}$ and not well captured by the testing 236 temperatures (Figs. 2, 3, 4 and 5).

\section{Seedling freezing tests}

In early spring (late March, Fig. 1), visible needle death was evident for all species after they were exposed to $-25^{\circ} \mathrm{C}$ and $-35^{\circ} \mathrm{C}$ for 30 minutes $(P<0.001$ for temperature effect) (Fig. 
241 6a). At the time of the freezing test, seedling cold hardiness determined by ambient thermal

242 accumulation (CGDH above $0{ }^{\circ} \mathrm{C}$ since January 1 was about 1500) on March dehardening curves

243 was $-25{ }^{\circ} \mathrm{C}$ for lodgepole pine, $-28{ }^{\circ} \mathrm{C}$ for jack pine, and $-31{ }^{\circ} \mathrm{C}$ for black and white spruce (Figs.

2443 and 5). Lodgepole pine was the only species with a substantial increase in needle death, from

$2455 \%$ to over $40 \%$, with a decrease in testing temperature from $-25{ }^{\circ} \mathrm{C}$ to $-35{ }^{\circ} \mathrm{C}$, although the

246 effects of tree species $(P=0.368)$ and species by temperature interaction $(P=0.083)$ were not

247 statistically significant. In the late spring freezing test (early May, Fig. 1), needle death exceeded

$24850 \%$ at $-10{ }^{\circ} \mathrm{C}$ and $-15^{\circ} \mathrm{C}$ for all 4 species $(P<0.001$ for temperature effect) (Fig. $6 \mathrm{~b})$ when the

249 cold hardiness determined by ambient thermal accumulation (CGDH was about 5800) on March

250 dehardening curves was $-9.8^{\circ} \mathrm{C}$ for lodgepole pine, $-11.5^{\circ} \mathrm{C}$ for jack pine, $-10.7^{\circ} \mathrm{C}$ for white

251 spruce, and $-13.4^{\circ} \mathrm{C}$ for black spruce, respectively. The point at which needle death occurred

252 differed among the 4 conifer species $(P=0.028)$, with the highest differences between white

253 spruce and jack pine.

254

\section{Discussion}

256 Our hypothesis that black and white spruce are slower to lose their cold hardiness than the pine

257 species during spring dehardening was only partially true. The 4 conifer species dehardened at

258 similar rates and to a similar extent as shown by the dehardening curves and fitted exponential

259 growth models, despite the fact that they differed considerably in timing of budbreak (Table 1;

260 Figs. 2, 3, 4, and 5). The relatively greater cold hardiness shown by black spruce at the late stage

261 of March dehardening is possibly due to its delayed budbreak. However, compared to the level

262 of cold hardiness prior to the artificial dehardening, differences were small and did not give

263 black spruce significant protection against late spring freezing temperatures at $-10{ }^{\circ} \mathrm{C}$ and $-15^{\circ} \mathrm{C}$ 
264 in early May (Fig. 6b) when bud swelling had not yet occurred. Comparatively, white spruce did 265 not show any advantage over the pine species in cold hardiness resulting from its late budbreak. Our assessments of cold hardiness prior to spring (March) dehardening were consistent

267 with those observed by Glerum (1973) who indicated that the maximum cold hardiness of spruce 268 and pine trees was well below $-40{ }^{\circ} \mathrm{C}$, while the minimum cold hardiness differed by several 269 degrees, likely reflective of the differences between mature needles used in this study and the 270 newly flushed needles in his study. The more gradual change of cold hardiness during winter 271 (December) dehardening could have resulted from incomplete fulfilment of chilling 272 requirements, as insufficient chilling is associated with a greater need for thermal accumulation 273 for budbreak in all 4 conifer species (Man, R., Lu, P., and Dang, Q.L., unpublished data). 274 Our findings suggest that dehardening of mature conifer needles continues during 275 budbreak (Glerum 1973; Bigras and Hébert 1996). For example, both jack and lodgepole pine 276 broke bud earlier than spruce and continued to lose cold hardiness during and after budbreak 277 (Fig. 3). Comparatively, changes in the cold hardiness of white and black spruce during 278 budbreak were small and may not be significantly sufficient to be captured by some of the 279 previous studies, which suggested that minimum cold hardiness in spruce is generally reached at 280 the time of budbreak (Peace 1962; Holzer 1969; Nienstaedt and King 1969). Lodgepole pine was relatively less cold hardy than the other conifer species as indicated 282 by cold hardiness levels at the beginning of winter dehardening and the end of spring 283 dehardening and the amount of needle death at $-35^{\circ} \mathrm{C}$ in early spring freezing tests. Halfpenny 284 and Ozannne (1989) reported considerable damage to lodgepole pine in Colorado during a false 285 spring when a warm spell (6-day mean maximum temperature of $6.4^{\circ} \mathrm{C}$ ) in January was 286 followed by severe cold in February (minimum temperature of $-34{ }^{\circ} \mathrm{C}$ ). Lodgepole pine also 
287 shows higher sensitivity to warming/temperature fluctuations and greater level of dehardening 288 than other conifers in controlled conditions (Nilsson 2001; Ögren 2001; Man et al. 2016). The 289 red belt damage, likely a result of winter freezing (Robin and Susut 1974; Man et al. 2013), 290 occurs on lodgepole pine more so than other boreal conifers (Robin and Susut 1974). Our results show that all 4 conifer species were vulnerable to freezing temperatures

292 following quick loss of cold hardiness during spring dehardening, as shown by the thermal 293 accumulations and night temperatures associated with 3 historical conifer winter browning 294 events (Fig. 5). Slower dehardening would give black spruce mature needles some level of 295 protection as they were less damaged than other conifers in reported winter browning events 296 (Cayford et al. 1959; Man et al. 2009), but more protection for this species may come from its 297 delayed new growth (Glerum 1973; Bigras et al. 2001). Compared to spruce, pine trees were 298 notably less hardy in early winter (Figs. 2 and 4), possibly due to their different capacities for 299 hardening (lodgepole pine) and dehardening (jack pine), and therefore have an additional 300 vulnerability to winter cold. The substantial increase in cold hardiness of jack pine following 10 days of cold storage at $0{ }^{\circ} \mathrm{C}$ indicated a greater capacity to re-harden and potentially reduce 302 vulnerability to freezing temperatures if the return to cold temperatures after warming is more 303 gradual (Pukacki and Kamińska-Rożek 2013; Man et al. 2016). Caution is required when applying the findings of this study to natural forests due to which may be offset by longer exposure to cold and stronger post-freezing radiation from sunlight and therefore more damage (Dang et al. 1992) — and between seedlings and mature trees in frost resistance (Sakai and Larcher 1987; Vitasse 2013). Nevertheless, the spring 
310 dehardening curves from REL and visual assessments were comparable and supported by the 311 results of whole seedling freezing tests (Fig. 6) and the observations from the reported conifer 312 winter browning events that occurred in spring prior to black spruce budbreak (Fig. 5) (Cayford 313 et al. 1959; Man et al. 2009, 2013). These dehardening curves can serve as tools to predict the 314 level of cold hardiness from natural thermal accumulations and inform understanding of the 315 potential effects of winter warming/freezing events that may increase in frequency and scale 316 under a warming climate (Schär et al. 2004; Rigby and Porporato 2008; Man et al. 2009;

317 Augspurger 2013; Strimbeck et al. 2015). Based on the findings of this study, the effects of 318 winter freezing may be reduced with northward migration of tree species, as southern 319 populations require more chilling and thermal accumulations for dormancy release and budbreak 320 (Howe et al. 2003).

\section{Acknowledgements}

323 We thank Darren Derbowka and Kevin Maloney of the Ontario Ministry of Natural Resources 324 and Forestry (OMNRF) for their assistance during the study, and Lisa Buse of OMNRF and two 325 anonymous reviewers for their constructive comments on an earlier version of this manuscript. 326 The conifer seedlings were provided by Tree Time Services Inc./Coast to Coast Reforestation, 327 Alberta, and Millson Forestry Service Inc., Ontario. 


\section{Literature cited}

Augspurger, C.K. 2013. Reconstructing patterns of temperature, phenology, and frost damage over 124 years: Spring damage risk is increasing. Ecology 94: 41-50.

Anderson, J.A., Kenna, M.P., and Taliaferro, C.M. 1988. Cold hardiness of Midiron and Tifgreen bermudagrass. HortScience 23: 748-750.

Bannister, P., and Neuner, G. 2001. Frost resistance and the distribution of conifers. In Conifer Cold Hardiness. Edited by F.J. Bigras and S.J. Colombo. Kluwer Academic Publishers, Dordrecht, Boston, Mass., USA. pp. 3-21.

Bigras, F.J., and Hébert, C. 1996. Freezing temperatures and exposure times during bud break and shoot elongation influence survival and growth of containerized black spruce (Picea mariana) seedlings. Can. J. For. Res. 26: 1481-1489.

Bigras, F.J., Ryyppö, A., Lindström, A., and Stattin, E. 2001. Cold acclimation and deacclimation of shoots and roots of conifer seedlings. In Conifer Cold Hardiness. Edited by F.J. Bigras and S.J. Colombo. Kluwer Academic Publishers, Dordrecht, Boston, Mass., USA. pp. 57-88.

Burr, K.E., Hawkins, C.D.B., L'Hirondelle, S.J., Binder, W.D., George, M.F., and Repo, T. 2001. Methods for measuring cold hardiness of conifers In Conifer Cold Hardiness. Edited by F.J. Bigras and S.J. Colombo. Kluwer Academic Publishers, Dordrecht, Boston, Mass., USA. pp. 369-401.

Cayford, J. H., V. Hildahl, L. D. Nairn and M.P.H. Wheaton. 1959. Injury to trees from winter drying and frost in Manitoba and Saskatchewan in 1958. For. Chron. 35:282-290.

Dang, Q.L., Lieffers, V.J., and R.L. Rothwell. 1992. Effects of summer frosts and subsequent shade on foliage gas exchange in peatland tamarack and black spruce. Can. J. For. Res. 22: 973-979.

Deans, J.D., Billington, H.L., and Harvey, F.J. 1995. Assessment of frost damage to leafless stem tissues of Quercus petraea: A reappraisal of the method of relative conductivity. Forestry 68: $25-34$.

Glerum, C. 1973. Annual trends in frost hardiness and electrical impedance for seven coniferous species. Can. J. Plant Sci. 53: 881-889.

Halfpenny J.C., and R.D. Ozannne. 1989. Winter: An Ecological Handbook. Johnson Publishing Company. Boulder, Colorado. 
360

361

362

363

364

365

366

367

368

369

370

371

372

373

374

375

376

377

378

379

380

381

382

383

384

385

386

387

388

389

Henson, W.R. 1952. Chinook winds and red belt injury to lodgepole pine in the Rocky Mountain parks area of Canada. For. Chron. 28: 62-64.

Holzer, K. 1969. Cold resistance in spruce. In Proceedings of the $2^{\text {nd }}$ FAO-IUFRO World Consultation on Forest Tree Breeding, 7-16 Aug., Washington, D.C., USA. pp. 597-613.

Howe, G.T., Aitken, S.N., Neale, D.B., Jermstad, K.D., Wheeler, N.C., and Chen, T.H.H. 2003. From genotype to phenotype: unraveling the complexities of cold adaptation in forest trees. Can. J. Bot. 81: 1247-1266.

Kalberer, S.R., Wisniewski, M., and Arora, R. 2006. Deacclimation and reacclimation of coldhardy plants: Current understanding and emerging concepts. Plant Sci. 171: 3-16.

Jönsson, A.M., Linderson, ., M.L., Stjernquist, I., Schlyter, P., and Bärring, L. 2004. Climate change and the effect of temperature backlashes causing frost damage in Picea abies, Global Planet. Change 44: 195-207.

Lund, A.E., and Livingston, W.H. 1999. Freezing cycles enhance winter injury in Picea rubens. Tree Physiol. 19: 65-69.

Man, R., Kayahara, G.J., Dang, Q.L., and Rice, J.A. 2009. A case of severe frost damage prior to budbreak in young conifers in northeastern Ontario: Consequence of climate change? For. Chron. 85: 453-462.

Man, R., and Lu, P. 2010. Effects of thermal model and base temperature on estimates of thermal time to bud break in white spruce seedlings. Can. J. For. Res. 40: 1815-1820.

Man, R., Colombo, S., Kayahara, G.J., Duckett, S., Velasquez, R., and Dang, Q.L. 2013. A case of extensive conifer needle browning in northwestern Ontario in 2012: Winter drying or freezing damage? For. Chron. 89: 675-680.

Man, R., Colombo, S., Lu, P., Li, J., and Dang, Q.L. 2014. Trembling aspen, balsam poplar, and white birch respond differently to experimental warming in winter months. Can. J. For. Res. 44: 1469-1476.

Man, R., Colombo, S., Lu, P., and Dang, Q.L. 2016. Effects of winter warming on cold hardiness and spring budbreak of four boreal conifers. Botany 94: 117-126.

Nienstaedt, H., and King, J.P. 1969. Breeding for delayed bud break in Picea glauca (Moench) Voss. In Proceedings of the $2^{\text {nd }}$ FAO-IUFRO World Consultation on Forest Tree Breeding, 7-16 Aug., Washington, D.C., USA. pp. 61-80. 
402

403 404

405

406

407

408

409

410

411

412

413

414

415

416

417

418

419

420

Nilsson, J.-E. 2001. Seasonal changes in phenological traits and cold hardiness of F1-populations from plus-trees of Pinus sylvestris and Pinus contorta of various geographical origins. Scand. J. For. Res. 16: 7-20.

Ögren, E. 2001. Effects of climatic warming on cold hardiness of some northern woody plants assessed from simulation experiments. Physiol. Plant. 112: 71-77.

Peace, T.R. 1962. Pathology of Trees and Shrubs, with Special Reference to Britain. Clarendon Press, Oxford, UK.

Pletsers, A., Caffarra, A., Kelleher, C.T. and Donnelly, A. 2015. Chilling temperature and photoperiod influence the timing of bud burst in juvenile Betula pubescens Ehrh. and Populus tremula L. trees. Ann. For. Sci. 72: 941-953.

Pukacki, P.M., and Kamińska-Rożek, E. 2013. Differential effects of spring reacclimation and deacclimation on cell membranes of Norway spruce seedlings. Acta Soc. Bot. Pol. 82: $77-84$.

Repo, T. 1992. Seasonal changes of cold hardiness in Picea abies and Pinus sylvestris. Can. J. For. Res. 22: 1949-1957.

Repo, T and Pelkonen, P. 1986. Temperature step response of dehardening in Pinus sylvestris seedlings. Scand. J. For. Res. 1: 271-284.

Rigby, J.R., and Porporato, A. 2008. Spring frost risk in a changing climate. Geophys. Res. Lett. 35: L12703.

Robin, J.K., and Susut, J.P. 1974. Red belt in Alberta. Can. For. Serv., Edmonton, AB. Inf. Rep. NOR-X-99.

Sakai, A., and Larcher, W. 1987. Frost Survival of Plants: Responses and Adaptation to Freezing Stress. Springer-Verlag, New York, N.Y.

Schär, C., Vidale, P.L., Lüthi, D., Frei, C., Häberli, C., Liniger, M.A., and Appenzeller, C. 2004. The role of increasing temperature variability in European summer heatwaves. Nature 427(6972): 332-336.

Silim, S.N., and Lavender, D.P. 1994. Seasonal patterns and environmental regulation of frost hardiness in shoots of seedlings of Thuja plicata, Chamaecyparis nootkatensis, and Picea glauca. C. J. Bot. 72: 309-316:

Snyder, R.L., Spano, D., Cesaraccio, C., and Duce, P. 1999. Determining degree-day thresholds from field observations. Int. J. Biometeorol. 42: 177-182. 
421 Strimbeck, G.R., Schaberg, P.G., DeHayes, D.H., Shane, J.B., and Hawley, G.J. 1995. Midwinter 422 dehardening of montane red spruce during a natural thaw. Can. J. For. Res. 25: 20404232044.

424 Strimbeck, G.R., Schaberg, P.G., Fossdal, C.G., Schröder, W.P., and Kjellsen, T.D. 2015.

425 Extreme low temperature tolerance in woody plants. Front. Plant Sci. 6: 1-15.

426 Vitasse, Y. 2013. Ontogenic changes rather than difference in temperature cause understory trees 427 to leaf out earlier. New Phytol. 198: 149-155.

428

429 
430 Table 1. Variance analysis and thermal accumulations (cumulative growing degree hours $>0{ }^{\circ} \mathrm{C}$ ) 431 required for budbreak in winter (December) and spring (March) dehardening experiments.

\begin{tabular}{lrrrr}
\hline Variance & Treatment effect & Species & Time & Species*Time \\
\cline { 2 - 5 } analysis & Probability $(P)$ & $<0.001$ & $<0.001$ & 0.227 \\
\hline Mean values & Lodgepole pine & Jack pine & White spruce & Black spruce \\
\hline Winter & 4381 & 3332 & 7880 & 9851 \\
Spring & 2899 & 1841 & 6030 & 8700 \\
\hline
\end{tabular}

432 


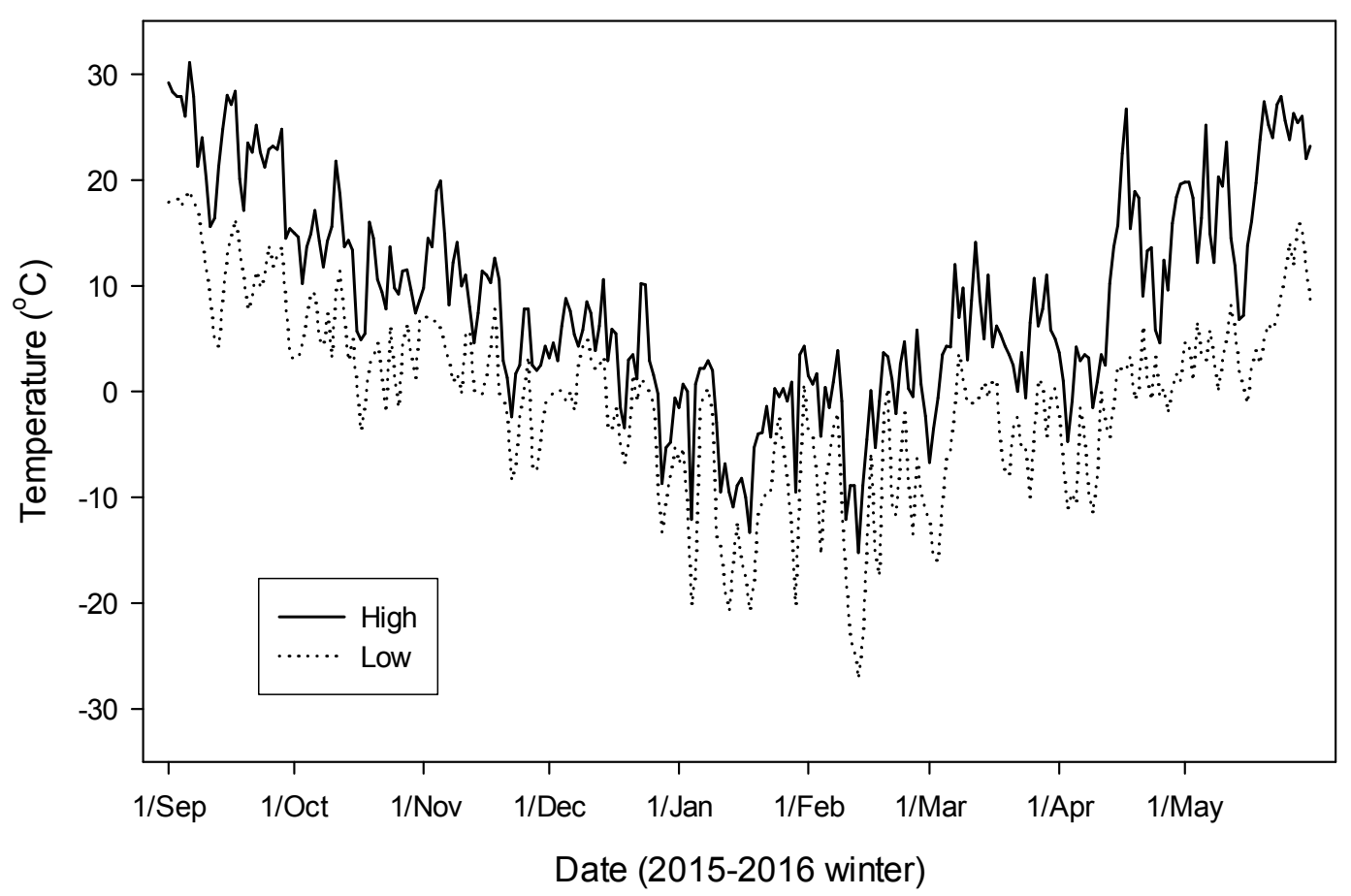

434

435

436 Fig. 1. Outdoor air temperatures (daily high and low) at the study location in Sault Ste. Marie, 437 Ontario, during winter 2015-16.

438 


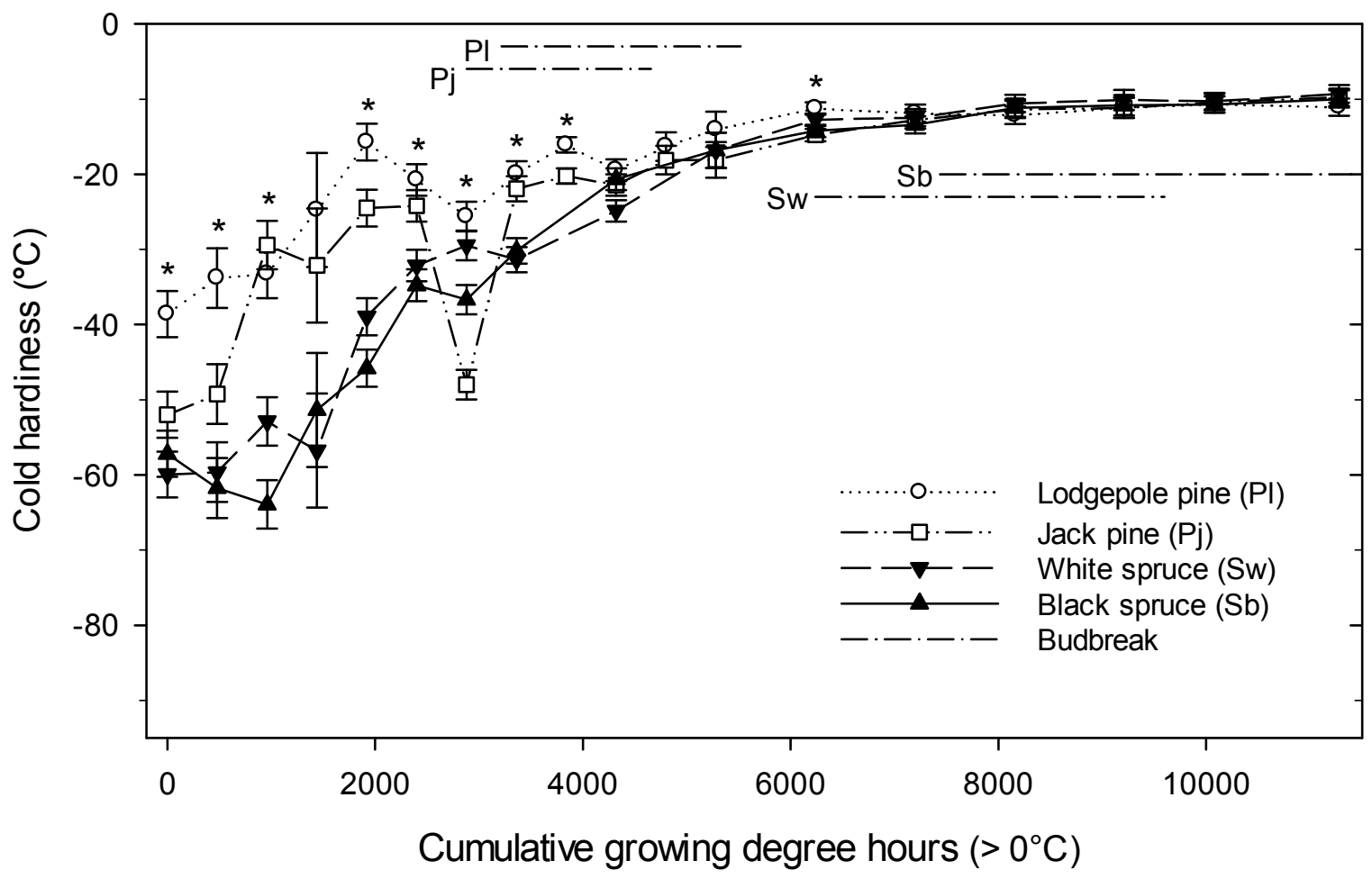

443 Fig. 2. Cold hardiness of 4 boreal conifers assessed based on changes in relative conductivity 444 during artificial dehardening in winter (December). Asterisks above points indicate significant 445 differences among species. 


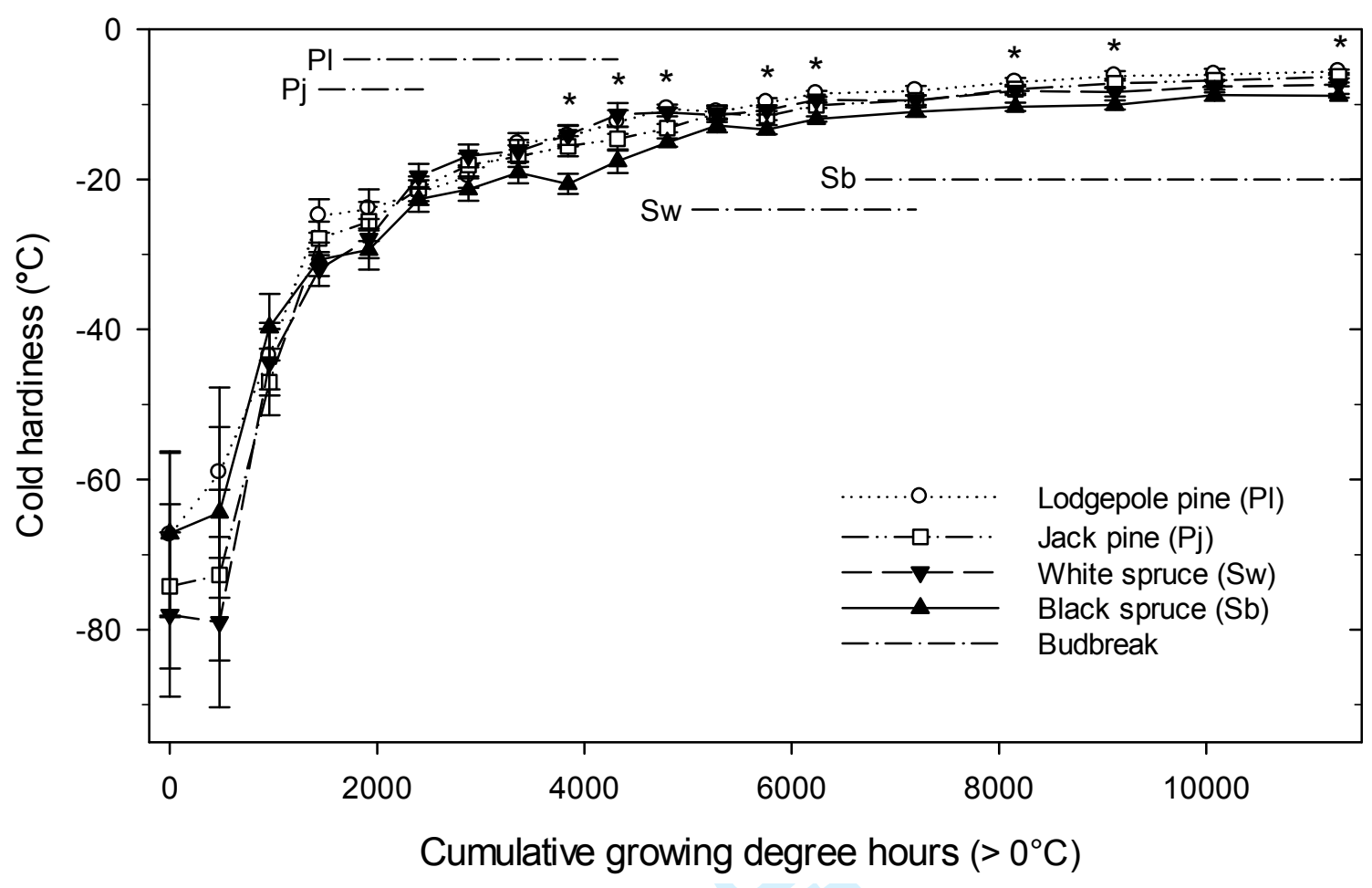

451 Fig. 3. Cold hardiness of 4 boreal conifers assessed based on changes in relative conductivity 452 during artificial dehardening in spring (March). Asterisks above points indicate significant 453 differences among species.

454

455 

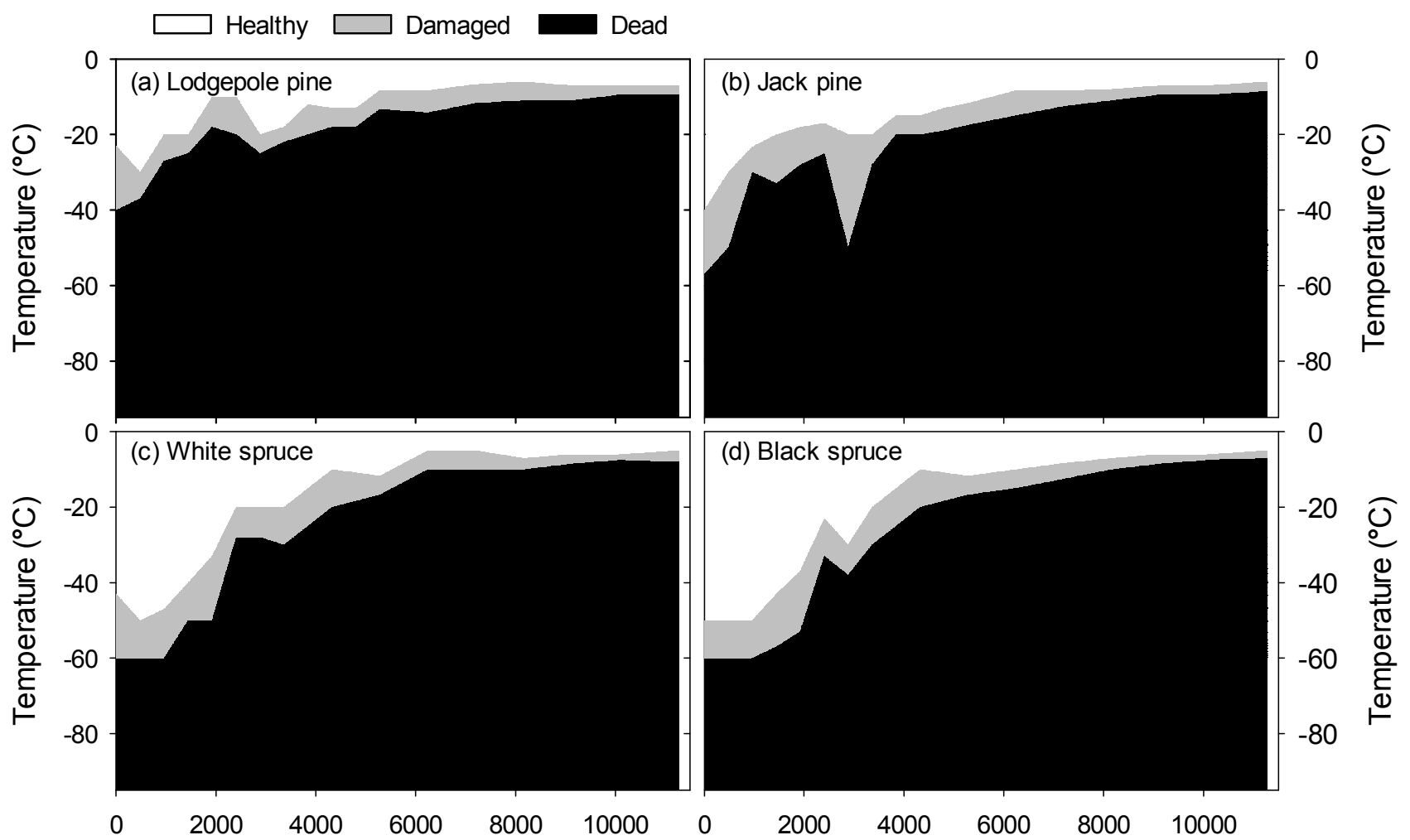

Cumulative growing degree hours $\left(>0^{\circ} \mathrm{C}\right)$

458 Fig. 4. Level of needle damage assessed visually after freezing tests during artificial dehardening 459 in winter (December). 

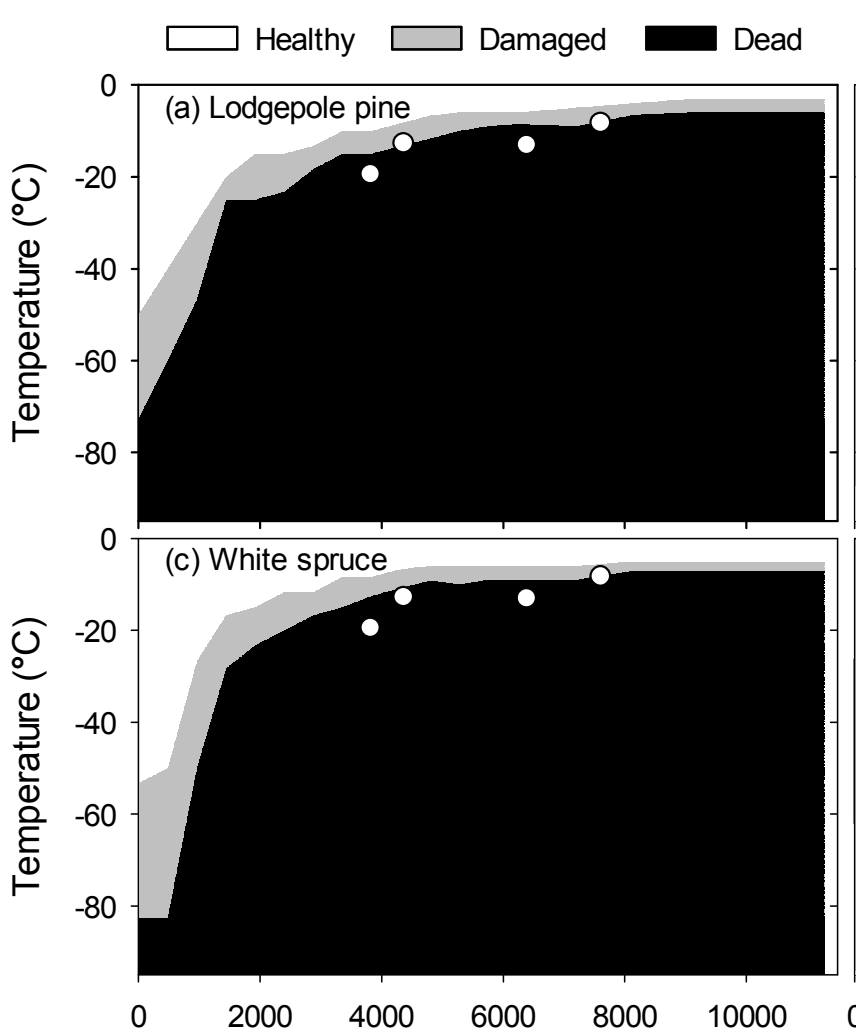

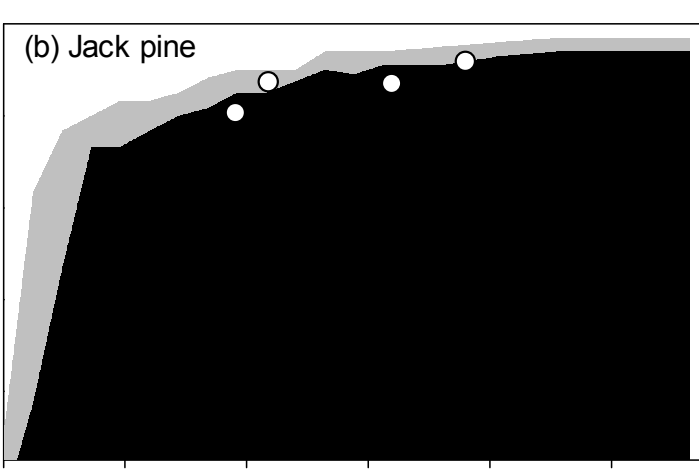

(d) Black spruce

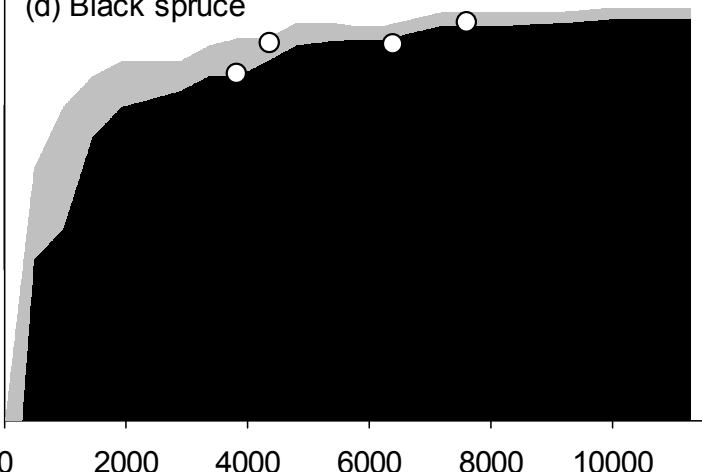

0

$-20$ $-40$ $-60$ $-80$ 0
464 Fig. 5. Level of needle damage assessed visually after freezing tests during artificial dehardening 465 in spring (March). White circles indicate the thermal accumulation (cumulative growing degree 466 hours $(\mathrm{CGDH})>0{ }^{\circ} \mathrm{C}$ ) and night temperatures from three historical conifer winter browning 467 events, 1958 in central Canada (CGDH $=6400$ on April 29), 2007 in northeastern Ontario $468(\mathrm{CGDH}=7600$ on May 19), and 2012 in northwestern Ontario (CGDH $=3800$ for the Geraldton 469 area and 4400 for Thunder Bay area on April 17).

470 


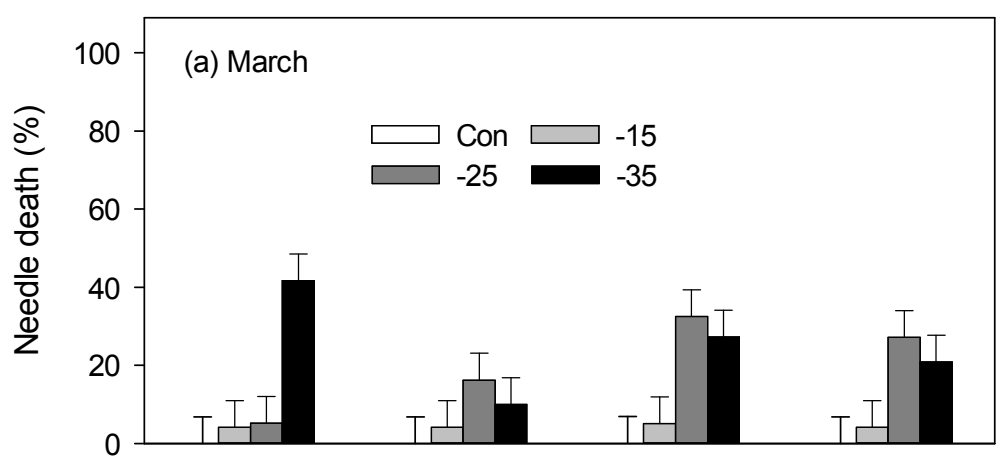

482

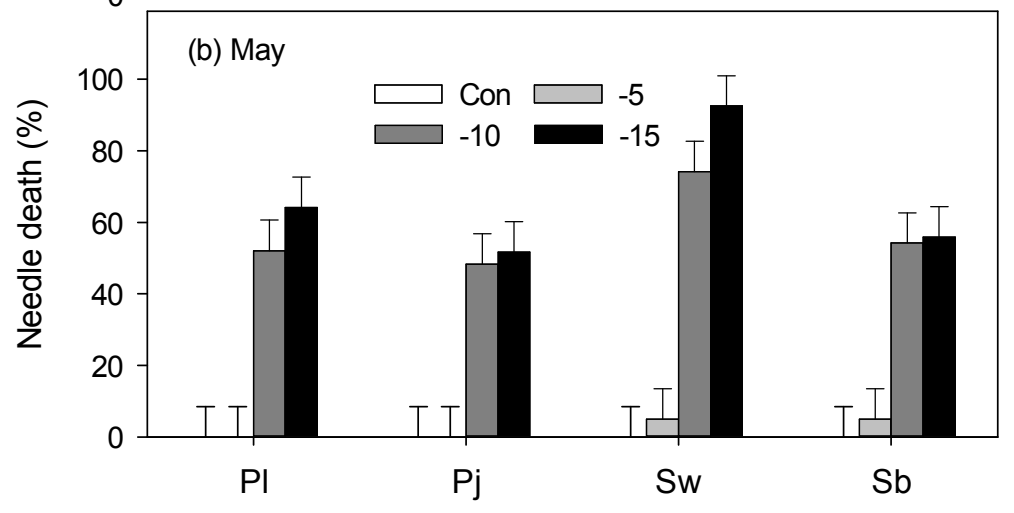

483

485 Fig. 6. Percent needle death of seedlings grown outdoors by species (Pl-lodgepole pine, Pj-jack 486 pine, Sw-white spruce, and Sb-black spruce), season, and testing temperature for seedling 487 freezing tests conducted in late March (19 - 21) and early May (2 - 4).

488 